\title{
PoLICY The road to the Inequalities in Health Alliance
}

\author{
Author: Andrew Goddard ${ }^{\mathrm{A}}$
}

In late 2020, the Royal College of Physicians (RCP) established the Inequalities in Health Alliance (IHA) to campaign for a cross-government strategy to reduce health inequalities. In this article, RCP president Prof Andrew Goddard charts the evolution of the IHA and explains what comes next.

KEYWORDS: inequality, health, policy

DOI: $10.7861 /$ fhj.2021-0021

\section{Introduction}

As we entered 2020, the Royal College of Physicians (RCP) already had a plan to bring together a large number of organisations as the Inequalities in Health Alliance. On the back of Health equity in England: The Marmot review 10 years on, we would campaign for a cross-government strategy to reduce health inequality.

While the COVID-19 pandemic made it more difficult to continue that work, it also made it more urgent. Over the past year, we have witnessed that the impact of health inequalities (unfair and avoidable differences in health across the population and between different groups within society) is immediate and significant. Deaths from COVID-19 are higher in areas of greater deprivation, delays in non-COVID treatment hit the most deprived the hardest, and Marcus Rashford, a Premier League footballer, has had to convince the government to feed the UK's poorest children. ${ }^{2}$

At the beginning of 2021, the IHA boasted almost 160 members. They include royal colleges, specialist societies, charities, think tanks, local authorities and NHS trusts.

Despite this breadth of support, achieving our aims in the current climate is not going to be easy, but the growing narrative in the NHS, media and government about inequality also presents us with an opportunity.

\section{Why health inequality and why now}

When I was elected, I was asked what single thing I wanted to 'achieve'; and my answer was and remains to double the number of medical students. I'm pleased to say that we are making slow but steady progress on this. However, over the past few years, I have realised that the influence the RCP can have on wider society is as significant as on specific NHS policy. I have also

Author: Apresident, Royal College of Physicians, London, UK experienced first-hand that the more power you have, the greater the responsibility to use it to help those who have very little, or none at all.

When it comes to that wider responsibility, it is the role of the RCP and its members in improving the health of the global population that stands out to me. It was the RCP that recognised the importance of only allowing qualified people to practice medicine. ${ }^{3}$ We opened the first public dispensary in England so the poorest people could get medicines for free. ${ }^{4}$ We have been at the forefront of highlighting the dangers of alcohol, smoking, obesity and air pollution. ${ }^{5-8}$

In 2018, when we were developing our priorities for influencing work, it was clear that the growing gap in healthy life expectancy was of great concern to RCP members. That life expectancy had stopped improving for the first time since 1982 was a worry, but the fact it had decreased in some areas was highly concerning. ${ }^{9}$

In March 2018, the Office for National Statistics reported statistically significant increases in the inequality in life expectancy in England between the most and least deprived..$^{10}$ In its Health profile for England: 2018, Public Health England said that there was no evidence that inequalities in life expectancy had narrowed: they had remained the same for men, and widened for women. ${ }^{11}$

But the starkest finding was that the gap in healthy life expectancy between the richest and poorest areas of England was around 19 years, for both men and women. ${ }^{11}$ That means that the most deprived people in our country spend a third of their lives in poor health, double that of the least deprived.

As a doctor, a dad, a UK citizen and, ultimately, a human being, that fact makes me feel a number of things: anger, dismay and shame. What it doesn't make me feel is impotent to do anything about it, especially when I am privileged to hold a position do something.

\section{RCP advisory group on health inequalities}

With the support of the membership, the RCP did what it does best: set up a working group. I jest slightly, but what I love about such groups is that they are never just talking shops. As doctors, we are used to doing, to just getting on with it, and the RCP exists to help facilitate that.

Chaired by our special adviser on population health, Prof Carol Brayne, the advisory group on health inequalities brings together our special advisers on public health issues, our Patient and Carer Network, our academic vice president and vice president for Wales, and others. We were also very pleased that Prof Sir Michael Marmot agreed to be the group's special adviser.

Over the past 18 months, the group has developed a strategy for the RCP, rooted in the excellent work on addressing health 
inequality that has been done in the past. In particular, Prof Sir Michael Marmot's 2010 report, Fair society, healthy lives, and the Black report, the work of one of my predecessors. ${ }^{12,13}$

In 1980, as many of you will know, Sir Douglas Black chaired the expert committee into health inequality, commissioned by the then Department of Health and Social Security. The Black report demonstrated that, although overall health had improved since the introduction of the welfare state, there were widespread health inequalities. It also found that the main cause of these inequalities was economic inequality..$^{13}$

Only 260 copies of the report were printed (one of which still sits in the RCP library) and it was introduced to the world on the August bank holiday. You might be forgiven for thinking perhaps there was something in it that the government didn't want to shout about.

In his introduction, the secretary of state said: 'I must make it clear that additional expenditure on the scale which could result from the report's recommendations - the amount involved could be upwards of $£ 2$ billion a year - is quite unrealistic in present or any foreseeable economic circumstances, quite apart from any judgement that may be formed of the effectiveness of such expenditure in dealing with the problems identified' (my emphasis).

In other words, 'you might be right but it's going to cost too much.' Or perhaps the committee had done its job too well, laying out in stark, non-political terms that the richer you are, the better your health. The 1998 Acheson report concluded the same, as did Fair Society, Healthy Lives. ${ }^{12,14}$

\section{Inequalities in Health Alliance}

Our advisory group identified two strands of work for the RCP: one inward looking, the other outward looking. The former has involved updating some of our courses related to health inequality, and we are developing new ones.

The outward looking work is embodied in the Inequalities in Health Alliance. In October 2020, we wrote to the prime minister to lay out what we think needs to be done and why:

$>$ a cross-government strategy to reduce health inequalities is required because health inequality is the result of many and varied factors

> we need to enact the socio-economic duty, section 1 of the Equality Act 2010 (which Theresa May scrapped) to make sure the impact of policies on the poorest in society is considered before final decisions are made $\mathrm{e}^{15,16}$

$>$ an approach to child health in all policies is required because the importance of the early years for adult outcomes is well known (and we gave the example that by allowing more and more children to become obese in the past, we increased their risk of dying from COVID-19 in the present).

You might ask: 'So what?' Some organisations have written a letter to the government, what will that achieve?

You would be forgiven! We are well aware of the difficulty in achieving these aims, especially in the context of COVID-19. If the Black report and Fair society, healthy lives, which laid it all out in stark terms, didn't make governments sit up and pay attention, how will we?

The answer lies in numbers; in the same way that the RCP can speak with authority because it represents thousands of doctors, as the IHA membership grows, it will become increasingly clear that the government needs to respond. As Prof Sir Michael
Marmot said on Radio 4 in January 2020, in response to a question about why nobody was listening to him and his reports:

Just recently in Britain, the Royal College of Physicians took the initiative to bring together a health inequalities alliance of the medical royal colleges and other organisations. When they launched it, there were 77 organisations involved. Since they launched it, a few weeks ago, there are now more than 140 signed up! They wrote to the prime minister when I launched my review and urged him to act on my recommendations. He may not be listening, but it's clear that others are. ${ }^{17}$

It's also not just a letter: IHA members are telling their members and beneficiaries about the campaign, successfully encouraging MPs to ask questions in parliament, and encouraging others to join us.

\section{Towards the government spending review}

When we didn't receive a reply from the PM, we asked the shadow secretary of state for health and social care, Jonathan Ashworth MP, to ask the PM why. ${ }^{18}$ Jonathan is a key ally on this work (he has said reducing health inequality is his passion) and we are pleased he has made the IHA a matter of parliamentary record already. ${ }^{19}$

The PM said he hadn't received our letter, so we rectified that, but were still awaiting a response at the time of writing. The plan now is to keep working with IHA members to raise the profile of the initiative and our asks. At the right time, we will encourage people to write to their MP to ask how the government is going to tackle these inequalities. Eventually the lack of a meaningful response will become embarrassing, for backbenchers if not the PM himself, and at that point we will see individual MPs supporting us. That will build the pressure on the government to recognise that this is something that the country wants (and needs) them to do.

This process may seem tortuous, but dogged determination to follow it and build momentum is how long-lasting change is made. The main political target this year is the government spending review. We expect it in autumn and anticipate it will lead to a multiyear settlement, following the postponement of the 2020 comprehensive spending review. The government must use the opportunity to add some money to the rhetoric about 'levelling up'.

I hope that the IHA will be a lasting testament to the power of the RCP. All the signs are there: the interest in the IHA from across the sector, the preoccupation with health inequalities in the main health think tanks, a chapter in The NHS long term plan, the requirement for all trust boards to appoint a named person to oversee addressing health inequalities and the requirement to build back services post-pandemic in such a way that they reduce health inequality.

In January 2021 at our conference, Medicine 2021, the secretary of state for health and social care said he would have focused on addressing health inequality in 2020 if it weren't for the pandemic. I can just about believe that he would have talked about it, drew attention to the long-term plan and gone on a tour of some of the most deprived parts of England, particularly those newly represented by the government.

What is less clear is whether or not the government as a whole will be braver than their predecessors in 1980. It's up to us to make sure they put our money where the evidence says it needs to go.

For further information or if you're an organisation wishing to join, then please visit www.rcplondon.ac.uk/iha. 


\section{References}

1 Marmot M, Allen J, Boyce T et al. Health equity in England: The Marmot review 10 years on. The Institute of Health Equity, 2020. www.health.org.uk/publications/reports/the-marmot-review-10years-on [Accessed 08 February 2021].

2 BBC News. Marcus Rashford: Food voucher U-turn after footballer's campaign. BBC News 2020 www.bbc.co.uk/news/uk-53065806 [Accessed 08 February 2021].

3 Royal College of Physicians. Timeline. RCP, 2021. https://history. rcplondon.ac.uk/timeline [Accessed 08 February 2021].

4 Royal College of Physicians. History of the Royal College of Physicians. RCP. www.rcplondon.ac.uk/about-us/who-we-are/history-royal-college-physicians [Accessed 08 February 2021].

5 Royal College of Physicians. Alcohol Health Alliance UK. RCP. www. rcplondon.ac.uk/about-rcp/whos-who/people/alcohol-health-alliance-uk [Accessed 08 February 2021].

6 Royal College of Physicians. Smoking and health (1962). RCP, 1962. www.rcplondon.ac.uk/projects/outputs/smoking-andhealth-1962 [Accessed 08 February 2021].

7 Royal College of Physicians. RCP calls for obesity to be recognised as a disease. RCP, 2019. www.rcplondon.ac.uk/news/rcp-callsobesity-be-recognised-disease [Accessed 08 February 2021].

8 Royal College of Physicians. Every breath we take: the lifelong impact of air pollution. RCP, 2016. www.rcplondon.ac.uk/ projects/outputs/every-breath-we-take-lifelong-impact-air-pollution [Accessed 08 February 2021].

9 Office for National Statistics. National life tables, UK: 2015 to 2017. ONS, 2018. www.ons.gov.uk/peoplepopulationandcommunity/ nationallifetablesunitedkingdom/2015to2017 [Accessed 08 February 2021].

10 Office for National Statistics. Inequality in life expectancy widens as improvements reverse among most deprived females. ONS, 2018. www.ons.gov.uk/news/newsinequalityinlifeexpectancywidensbirthsdeathsandmarriages/lifeexpectancies/bulletins/ asimprovementsreverseamongmostdeprivedfemales [Accessed 08 February 2021].
11 Public Health England. Health profile for England: 2018. PHE, 2018. www.gov.uk/government/publications/health-profile-forengland-2018/chapter-5-inequalities-in-health [Accessed 08 February 2021].

12 The Marmot Review. Fair Society, Healthy Lives. The Marmot Review, 2010. www.instituteofhealthequity.org/resources-reports/ fair-society-healthy-lives-the-marmot-review [Accessed 08 February 2021].

13 Department of Health and Social Security. Inequalities in health: Report of a research working group. London: DHSS, 1980.

14 Committee of Inquiry into the Future Development of the Public Health Function. Public health in England: Report of the Committee of Inquiry into the Future Development of the Public Health Function (Cm 289). London: The Stationery Office, 1988.

15 Equality Act 2010. www.legislation.gov.uk/ukpga/2010/15/part/1 [Accessed 08 February 2021].

16 Home Office. Socio-economic duty to be scrapped. Home Office, 2010. www.gov.uk/government/news/socio-economic-duty-to-bescrapped [Accessed 08 February 2021].

17 BBC Radio 4. Rethink fairness: Health. BBC Sounds, 2021:35m 20s. www.bbc.co.uk/sounds/play/m000qxzl [Accessed 08 February 2021].

18 UK Parliament. Rt Hon Jonathan Ashworth MP: Written questions. UK Parliament. https://members.parliament.uk/member/4244/ writtenquestions\#expand-1258710 [Accessed 08 February 2021].

19 Independent. 'This is my passion': Health inequalities must be better tackled in UK, says Labour's Jonathan Ashworth. Independent 2020. www.independent.co.uk/news/health/jonathan-ashworth-coronavirus-nhs-health-inequality-a9560401.html [Accessed 08 February 2021].

Address for correspondence: Prof Andrew Goddard, Royal College of Physicians, 11 St Andrew's Place, Regent's Park, London NW1 4LE, UK.

Email: Andrew.Goddard@rcplondon.ac.uk 